\title{
The Effect of Teaching Approaches and Self-Efficacy on the Students' Achievement in Reading Comprehension
}

\author{
Dina Rahma Br Ginting \\ English Applied Linguistics \\ State University of Medan, UNIMED \\ Medan, Indonesia \\ Dinarahma25@gmail.com
}

\author{
I Wayan Dirgeyasa, Rahmad Husein \\ English Applied Linguistics \\ State University of Medan, UNIMED \\ Medan, Indonesia
}

\begin{abstract}
This research focused on the students ability in reading comprehension because reading comprehension is a fundamental for English foreign learner in observing new information and knowledge. Thus, this study was going to find out the effect of teaching approaches and self efficacy on the students' achievement in reading comprehension. This study would be carried out by applying a quantitative method. The population of this research was all the students of grade ten in senior high school of MAN Kabanjahe. The sample of research was taken by cluster random sampling technique. The result of this study revealed that the students with high self efficacy tend to more interested in accomplishing task. They also have a good effort and desire to get the information from the text. Meanwhile, those who have low self efficacy will have less capability in finding new ideas or information. Otherwise, comparing the two approaches and selfefficacy, it can be concluded that there is an interaction between teaching approaches and self efficacy on the students' achievement in reading comprehension.
\end{abstract}

Keywords — reading, teaching approaches, self-efficacy

\section{INTRODUCTION}

Reading is a very complex skill and for this reason it is not surprising to find that some students encounter difficulties in learning to read [1]. By reading, students are expected to get the knowledge and to understand the context from that has been explained in the text. But, nowadays, the fact is the students do not know the essential of reading itself. They just read the text without getting the meaning. This is related to the student's ability in understanding the text. Most of the students are confused in processing the information in phrases and sentences. They can't connect the relationship between sentences [2]. They just tend to translate the words, one by one word to understand the meaning. They could not give their best performance in activities that they do not like, as the result, most students are being passive during the reading activities.

The consequences in the context of MAN Kabanjahe the condition can be seen from their achievement in reading that most of them cannot get the minimum completeness criterion $(\mathrm{KKM}=$ Kriteria Ketuntasan Minimal) that is 80 in their daily examination which is done in every month. This is actually the phenomenon teacher faced in the class in MAN Kabanjahe. The achievement of $\mathrm{X}$ grade students in learning English showed that the students' achievement in reading got the lowest score among for skills, the mean score of students' achievement in reading was 65.76. On the other hand, they could not achieve the minimum completeness criterion that has been decided by the school.

Based on that fact above, the teachers should use certain approaches which are suitable for the students and also to the teaching English material, in this case teaching reading comprehension. In order to get the optimum result of teaching reading, they need to be taught a range of teaching approaches and be encouraged to reflect on their own understanding and learning. Teaching approaches can affect the students' achievement in learning English, especially in reading comprehension. It can arouse students' motivation in learning [3]. Besides, teaching approaches significantly affected students' learning outcomes and were effective to be used [4]. It can be concluded that appropriate approaches can affect the students' achievement in learning English. Actually, there are so many teaching approaches that can be used by the teacher to teach the student in reading comprehension, two of them are scientific approach and genre based approach.

Finding the suitable approach in teaching learning process is not enough, there is another aspect that could influence the students' performance during teaching learning process. There must be serious attention from the teacher to know the students' internal factors to read and to activate their motivation [5]. Giving motivation to the students is not enough by applying the teaching approaches, to improve the quality of teaching learning process in the classroom it is important to include the students' internal factors, such as: curiosity, motivation, self-regulation and self-efficacy.

Self-efficacy is the belief and confidence that people have about their capability to accomplish meaningful task and produced a desired result in academic setting [6]. By knowing the students' self-efficacy, the teacher could help the students to exercise their capability during teaching learning process in the class by applying appropriate approaches and it also help them to improve their achievement in reading comprehension. 
Based on the description above, it can be concluded that the students' achievement in reading comprehension is not only influenced by teaching approaches but it also influenced by the student' self-efficacy. Therefore, this study would like to find out and describe the effect of teaching approaches and self-efficacy on the students' achievement in reading comprehension".

\section{LITERATURE REVIEW}

\section{A. The Students' Achievement in Reading Comprehension}

An achievement is a process of developing skill or knowledge, measureable and more stable cognitive trait. The students' achievement is an indicator in measuring the successful of teaching learning process. The achievement shows the process of capability development in someone ability comprehend the text [7].

Comprehension is the ability of one to find, interpret, and use ideas [8]. Otherwise, the achievement in reading is the result of bringing a concept to the text and relating it with the meaning got from the text, in which it is usually understanding it and giving responses as interpretation of the process in comprehending the text.

It can be concluded that achievement is the result achieved of an activity that already done in learning process through skill or knowledge and training.

\section{B. Reading Compprehension}

Reading comprehension is an extraordinary feat of balancing and according many abilities in a very complex and rapid set of routines that makes comprehension a seeing effortless and enjoyable activity for fluent readers. It means that is not only recognizing words but also thinking responding [9]. There are some levels of reading comprehension. The following levels of comprehension can tell us about how far the students understand about reading material and which level has been achieved. There are three levels of reading comprehension, they are: literal, inferential and critical comprehension [10].

\section{Scientific Approach}

Scientific approach is defined as the process of finding out information in science, which involves testing the ideas by performing experiments and making decisions based on the result of analysis [11]. It means that scientific approach is a body of techniques for investigating phenomena, acquiring new knowledge, and correcting and integrating previous knowledge. This approach allows teachers to improve the process of learning by breaking the process down into steps or stages which contains detailed instructions for conducting students learning. So, the teaching learning process in scientific approach referred to the process of observing, asking, reasoning, experimenting, and establishing network for all subjects

\section{Genre Based Approach (GBA)}

GBA is also known as text-based instruction. Text-based instruction or genre-based approach is the kind of approach that sees communicative competence as involving the mastery of different types of texts [12]. The text here is used in a special sense referred to structured sequences of language that are used in specific context in specific ways. Therefore, Genre Based Approach is a supported approach to make students achieve the skills (reading, listening, speaking, and writing) and language elements (structure and vocabulary) enclosed on the ability to create a written or oral text.

\section{E. The Self-Efficacy}

Self-efficacy is defined by one's level of confidence and is the prime factor responsible for his/her ability to execute actions toward achieving a desirable outcome for a given required task [13]. Further, "self-efficacy beliefs determine how people feel, think, motivate themselves and behave. Such beliefs produce these diverse effects through four major processes. They include cognitive, motivational, affective and selection processes" [6]. In distinguishing an individual with a strong sense of efficacy and an individual who does not possess such efficacy, further noted that "an efficacious outlook fosters intrinsic interest and deep engrossment in activities". In that, persons with a strong sense of self-efficacy are more willing to set challenging goals for themselves while maintaining a strong commitment to accomplish these goals.

Self-efficacy can have an impact on everything from psychological states to motivation to behavior [6]. One's selfefficacy plays a major role on how they approach challenges and execute a task at hand or a goal. Individuals with a healthy sense of self-efficacy, in comparison to a person with a poor sense of self-efficacy, tend to have a stronger sense of commitment to their interests and activities, develop a deeper interest in the activities in which they participate, see challenging problems as tasks to be mastered, and recover quickly from setbacks and disappointments [6]. In contrast, individuals with a poor sense of self-efficacy tend to focus on personal failings and negative outcomes, quickly lose confidence in personal abilities, avoid challenging tasks, and tend to believe that difficult tasks and situations are beyond their capabilities.

\section{RESEARCH METHODOLOGY}

This study would be carried out by applying a quantitative method. Quantitative methods emphasize objective measurements and the statistical, mathematical, or numerical analysis of data collected through polls, questionnaires, and surveys, or by manipulating pre-existing statistical data using computational techniques. Quantitative research focuses on gathering numerical data and generalizing it across groups of people or to explain a particular phenomenon [14]. This study used quantitative method to measure the students' achievement in reading comprehension by applying teaching approaches.

\section{A. Population and Sample}

This research would be conducted in Senior High School (Madrasah Aliyah Negeri), Kabanjahe. The Population of this research was all the students of grade $\mathrm{X}$ in the academic year 2017/2018. There were 6 classes as the population for this research. The total number of population in 
this study was192 students. The sample of research was taken by cluster random sampling technique. Cluster random sampling is the sample group of subjects that are selected by chance. It would be used only to consider two classes from 6 classes in the grade $\mathrm{X}$ selected as the representative of the population. Units

\section{B. The Instrument of Data Collection}

There were two instruments used in this research, namely self-efficacy questionnaire (to know the students' self efficacy) and reading comprehension test (to know the effect of teaching approaches on reading comprehension). The selfefficacy questionnaire consisted of 20 items while the reading comprehension test consisted of 40 questions.

\section{Validity}

\section{- Self-Efficacy Questionnaire}

The validity coefficient of the students' self- efficacy questionnaire could be computed by employing the Pearson Product Moment formula [15]. The formula is as the following:

$$
r_{x y}=\frac{N\left(\sum x y\right)-\left(\sum x\right)\left(\sum y\right)}{\sqrt{\left(N\left(\sum_{x} 2\right)-\left(\sum x\right)^{2}\left(N\left(\sum Y^{2}\right)-\left(\sum Y\right)^{2}\right)\right.}}
$$

\section{- Reading Comprehension Test}

There were three kinds of validity which might be used for research in education namely content validity, criterion related validity and construct validity [16]. In fact, this research will be only used the content validity because only this kind validity which represents the content of interest. In order to have content validity, a measure must adequately sample both the topics and the cognitive process included in the content universe under consideration. Therefore, the test containing forty questions in multiple choices are tried out to the students in the order to obtain the validity of the test at first.

\section{Reliability}

- Self-efficacy Questionnaire

The reliability of self-efficacy questionnaire was intended to see how far this instrument can give the same result if it is tested to same subject. To obtain the reliability of questionnaire, the researcher used Cronbach Alpha formula.

\section{- Reading Comprehension Test}

The reliability was the characteristics of a good test. It referred to the consistency of the test whether it was a good test or not. To obtain the reliability of test, the Kuder-Richardson formula was administered in this research. The value of reliability $\left(\mathrm{r}_{11}\right)$ will compare with the value of reliability of table $\left(\mathrm{r}_{\text {table }}\right)$ with $\alpha=$ 0.05 . The item test will reliable if the value of $r_{11}>$ $\mathrm{r}_{\text {table. }}$.

\section{The Technique of Analyzing Data}

The technique of analyzing data which would be used in this research is two way analysis of variance (ANOVA) with the level of significance $\alpha=0.05$. It would be used to test the hypothesis which have made at the previous part so the result of this research will be gathered.

Before the technique of analysis data used, there are two important things which is needed to be tested, namely normality and homogeneity of the test. Normality test would be used to determine whether the sample used come from the normal distribution or not. The normality test would be tested by using Liliefors. Homogeneity test would be used to determine whether the variance of the population is homogenous or not. It is homogenous if $F>0.005$. The calculation of this homogeneity test would be tested by using F-test and Barlett-test. After testing the hypotheses with twoway ANOVA the further test would be carried out by using Tuckey test.

\section{RESEARCH FINDINGS}

The research findings showed that both scientific and genre based approach have significant effect on the students' achievement in reading comprehension. It's proven by the average score on students' achievement in reading comprehension by using Tuckey test can be seen in table 4.1 .

\begin{tabular}{|l|l|l|l|}
\hline \multicolumn{2}{|l|}{ Statistical Hypothesis } & Qbserved & $Q_{\text {table }}$ \\
\hline Ho: $\mu \mathrm{A} 1 \mathrm{~B} 1=\mu \mathrm{A} 1 \mathrm{~B} 2$ & Ha: $\mu \mathrm{A} 1 \mathrm{~B} 1>\mu \mathrm{A} 1 \mathrm{~B} 2$ & 13.63 & \\
Ho: $\mu \mathrm{A} 1 \mathrm{~B} 1=\mu \mathrm{A} 2 \mathrm{~B} 1$ & Ho: $\mu \mathrm{A} 1 \mathrm{~B} 1>\mu \mathrm{A} 2 \mathrm{~B} 1$ & 3.79 & \\
Ho: $\mu \mathrm{A} 2 \mathrm{~B} 1=\mu \mathrm{A} 2 \mathrm{~B} 2$ & Ho: $\mu \mathrm{A} 2 \mathrm{~B} 1>\mu \mathrm{A} 2 \mathrm{~B} 2$ & 11.64 & 2.79 \\
Но: $\mu \mathrm{A} 2 \mathrm{~B} 2=\mu \mathrm{A} 1 \mathrm{~B} 2$ & Ho: $\mu \mathrm{A} 2 \mathrm{~B} 2>\mu \mathrm{A} 1 \mathrm{~B} 2$ & 7.85 & \\
Но: $\mu \mathrm{A} 1 \mathrm{~B} 1=\mu \mathrm{A} 2 \mathrm{~B} 2$ & Ho: $\mu \mathrm{A} 1 \mathrm{~B} 1>\mu \mathrm{A} 2 \mathrm{~B} 2$ & 8.84 & \\
Но: $\mu \mathrm{A} 2 \mathrm{~B} 1=\mu \mathrm{A} 1 \mathrm{~B} 2$ & Нo: $\mu \mathrm{A} 2 \mathrm{~B} 1>\mu \mathrm{A} 1 \mathrm{~B} 2$ & 9.82 & \\
\hline
\end{tabular}

The criteria of accepting the hypothesis if $\mathrm{Q}_{\text {observed }}>\mathrm{Q}_{\text {table }}$, so there were significant differences to the level significant $\alpha=$ 0.05 . Based on the result of comparison by using Tuckey Test, it can be described that the comparison sample group were:

1. There were differences between the students' achievement in reading comprehension with high self-efficacy taught by using Scientific Approach and with low self-efficacy taught by scientific approach, it can be shown by the score of $\mathrm{Q}_{\text {observed }}=13.63>\mathrm{Q}_{\text {table }}$ $=2.79$.

2. There were differences between the students' achievement in reading comprehension with high self-efficacy taught by using Scientific Approach and with high self-efficacy taught by Genre Based Approach, it can be shown by the score of $\mathrm{Q}_{\text {observed }}$ $=3.79>\mathrm{Q}_{\mathrm{table}}=2.79$. 
3. There were differences between the students' achievement in reading comprehension with high self-efficacy taught by using Genre Based Approach and with low self-efficacy taught by Scientific Approach, it can be shown by the score of $Q_{\text {observed }}$ $=11.64>\mathrm{Q}_{\text {table }}=2.79$.

4. There were differences between the students' achievement in reading comprehension with low selfefficacy taught by using Genre Based Approach and with low self-efficacy taught by Scientific Approach, it can be shown by the score of $\mathrm{Q}_{\text {observed }}=7.85>\mathrm{Q}_{\text {table }}$ $=2.79$.

5. There were differences between the students' achievement in reading comprehension with high self-efficacy taught by using Scientific Approach and with low self-efficacy taught by Genre Based Approach, it can be shown by the score of $\mathrm{Q}_{\text {observed }}$ $=8.84>\mathrm{Q}_{\text {table }}=2.79$.

6. There were differences between the students' achievement in reading comprehension with low selfefficacy taught by using Scientific Approach and with high self-efficacy taught by Genre Based Approach, it can be shown by the score of $\mathrm{Q}_{\text {observed }}$ $=9.82>\mathrm{Q}_{\mathrm{table}}=2.79$.

Based on the data analysis, it showed that both Scientific Approach and Genre Based Approach have significant effect on the students' achievement in reading comprehension. It can be seen by the total mean both of the teaching approaches, it shows that the students taught by using Scientific Approach have higher achievement than students taught by using Genre Based Approach. It is because the scientific approach can enhance the students' creativity, the students more thinking critically and accurately in identifying, comprehending text, and solve problems [17]. Thus, it can be concluded that scientific approach is a learning approach which could make the students work actively in constructing concepts and principles through the stages observed (to identify or find the problem), to formulate the problem, propose or formulate hypotheses, collect data with a variety of techniques, analyzing the data, draw conclusions and communicate the concept. This approach is very helpful to help the students in comprehending the text.

Then, the result of F-test calculation shows that there is significant difference on achievement in reading comprehension between high and low selfefficacy students. The total mean indicates that the students' achievement with high self-efficacy is higher than students those have low self-efficacy. It happened because the students with high self-efficacy attempt more, accomplish more and persist longer at a specific task compared to individuals with low selfefficacy conversely, individuals with low selfefficacy tend to avoid difficult tasks and will often give up sooner if the activities are challenging [18].
Thus, the Tuckey test indicates that the students' with high self-efficacy is worthy if it is matched with Scientific Approach while the students with low self-efficacy is worthy if it is matched with Genre Based Approach. Based on the data of two way analysis (ANOVA), the students achievement in reading comprehension with high self-efficacy that was taught by using Scientific Approach is higher than by using Genre Based Approach, it can be shown by the score 35.50 and 32.80. It means that Scientific Approach is better to improve the students' achievement in reading comprehension than Genre Based Approach. Meanwhile, the students' achievement in reading comprehension with low self-efficacy that was taught by using Genre Based Approach is higher than by using Scientific Approach, it can be shown by the score 27.20 and 26.50. It means that Genre Based Approach is better to improve students' achievement in reading comprehension than Scientific Approach for the students who have low selfefficacy.

On the other hand, it can be concluded that the students' achievement in reading comprehension is influenced by teaching approaches and self-efficacy. The high self-efficacy students showed significant effect on their reading comprehension achievement if they were taught by using Scientific Approach while low self-efficacy students showed significant effect on their reading achievement if they were taught by using Genre Based Approach.

\section{REFERENCES}

[1] Westwod, Peter. 2001. Reading and Learning Difficulties. Australia: Acerpress

[2] Rahmi, Yunisa \& Ratmanida. 2014. The Use of Discovery Learning Strategy in Teaching Reading Report Text to Senior High School Students. JELT. Vol, 3. No. Serie C, pp.180.

[3] Ningsih, W.D. 2015. The implementation of genre based approach in teaching reading: a case study at Smpn 17 in Pekanbaru. Journal English Language Teaching (ELT) Volume 1 Nomor 1, p. 1-7

[4] Efrini, Multi. 2016. Discovery Learning Method Based on Scientific Approach in Curriculum 2013 in Teaching English at Senior High School. International Seminar on Education 2016.

[5] Guthrie, J.T., Perencevich, C.K. \& Wigfield, A. 2004. Motivating Reading Comprehension: Concept Oriented Reading Instruction. New Jersey: Lawrence Erlbaum Associates, Inc.

[6] Bandura, A. 1997. Self-Efficacy: The Exercise of Control. New York: Freemen

[7] Bloom, B., Englehart, M.D., Frust, E.J \& Krathwohl, D. 1982 Taxonomy of Educational Objectives: Handbook 1, Cognitive Domain. New York: David McKay.

[8] Hayland, K. (2004). Genre and Second Language Writing. Ann Arbor: The university of Michigan Press.

[9] Grabe, W \& Stoler, L.F. 2002. Teaching and Researching Reading, England: Person Education.

[10] Brassel, D \& Rasinski, T. 2008. Comprehension that Works. CA Huntington Beach.

[11] Spear-Swerling, L. 2006. Fourth-graders' Performance on a Statemandated Assessment Involving Two Different Measures of Reading Comprehension. Reading Psychology,25, pp.121-148

[12] Richards, J.C. 2007. Curriculum Development in Language Teaching. Cambridge: Cambridge Language Education.

[13] Pajares, F., Hartley, J., \& Valiante, G. (2001). Response format in writing self-efficacy assessment: Greater discrimination 
increases prediction. Measurement and Evaluation in Counseling and Development, 33, 214-221.

[14] Babbie, Earl R. 2010. The Practice of Social Research. 12th ed. Belmont, CA: Wadsworth Cengage.

[15] Gregory, R. J. 2000. Psychological Testing (3rd ed.) Needham Heights, MA : Allyn \& Bacon.

[16] Ary, D., Jacobs, L.C \& Sorensen, C . 2010. Introduction to Research in Education. Canada: Nelson Education.

[17] Untari, D Septiana. 2017. The Implementation of Scientific Approach in Teaching Reading Comprehension for the Tenth Grade Students of SMA 2 Karanganyar in 2016/2017 academic year. IAIN Surakarta. Unpublish. 